\title{
Curtailing grazing-induced erosion in a small catchment and its environs, the Peak District, Central England
}

R. Evans, Department of Geography, APU, East Road, Cambridge, CB1 1PT, UK; email r.evans@apu.ac.uk

\begin{abstract}
Eroding slopes within a small catchment in the Peak District, Central England, and its environs have been monitored since 1966. A reduction in sheep grazing pressure in the late 1960s, due to a harsh winter and a poor crop of lambs, led to colonisation of bare soil on lower slopes, but not on higher exposed slopes. Sheep grazing pressure was permanently reduced in the 1980s as part of a new grazing regime. Many formerly eroding sheep scars in the small catchment have over time become completely colonised by vegetation and only those scars still actively used by sheep remain. It took two decades before vegetation began to invade the bare soil on the higher slopes. There, it was not until all the peat and the underlying leached (Ea) soil horizon was stripped off that vegetation was re-established. Colonisation is a rapid process and $c .80 \%$ of the bare soil is covered within 5-10 years. Factors other than sheep grazing pressure that exacerbated erosion were a cooling climate in the 1960s and the presence of cattle on the slopes. Temperatures have risen since then and cattle no longer graze the slopes.
\end{abstract}

Key words: Sheep; Grazing; Erosion; Peat; Vegetation colonisation

\section{Introduction}


In 1966 grazing-induced erosion in the uplands of Britain was not considered a problem (Evans, 1971). Overgrazing was something that happened elsewhere in the world. Now, in England and Wales (EA, 2000), as in much of the world (Oldeman et al., 1991; Evans, 1998), grazinginduced erosion is considered a problem that must be tackled. In many parts of the world it is the main cause of soil degradation.

In 1966 a two year study was begun of slope erosion processes in a small catchment in the Peak District, central England. One of the results of the study (Evans, 1974) was that sheep appeared to be the major cause of soil erosion, both initiating bare soil and maintaining it. In 1974 it was found that much of the previously eroding bare soil had become colonised by vegetation and this was attributed to a reduction in the number of sheep grazing the catchment (Evans, 1977). This suggestion was confirmed by subsequent work (Phillips, Yalden \& Tallis, 1981). The number of sheep declined because in the harsh spring of 1969 many lambs died. It was suggested that a 25$33 \%$ reduction in the number of sheep grazing the catchment had been sufficient to bring these changes about. Later monitoring confirmed the continuity of these changes (Evans, 1990).

The reduction in the number of sheep grazing the moors in 1969 did not appear to curtail erosion on nearby slopes at higher, more exposed altitudes (Evans, 1990). Bare soils on these slopes only started to become stabilised by vegetation in the late 1980s after the number of sheep grazing the moors had been reduced as a result of a management agreement made in the early 1980s between the National Trust and its tenant farmer. Later, vegetation began to colonise the eroding bare soil (Evans, 1992 \& 2000).

The increase in number of sheep on the Peak District moors came about because of the passing of the Agriculture Act in 1947 which authorised that farmers should be paid on the basis of the number of sheep they had. The increase in number of sheep was accompanied by a decline of heather moor (Anderson \& Yalden, 1981), the favoured habitat of the red grouse (Lagopus 
lagopus) which was also suffering a decline in numbers (Yalden, 1972). The reduction in number of sheep grazing the moors was brought about primarily because of the wish by the Peak District National Park Authority and the National Trust, a major land owning charity set up in 1895 to preserve beautiful countryside, to stop the decline in area of heather moor and reverse the fall in numbers of grouse. It was considered by the authorities that an increase in area of heather moor would be accompanied by an increase in the number of grouse and that would enable the shooting of game birds to become a profitable option or sideline to rearing sheep.

The number of sheep grazing the moors owned by the National Trust was reduced in the midand later 1980s (Wilson 1993; Anderson \& Radford, 1994). As a result, by the early 1990s, eroding moors to the west of those monitored here were colonised by vegetation (Anderson \& Radford, 1994). Vegetation invaded bare mineral soil successfully on lower (480m), less steep $\left(c .11^{\circ}\right)$ slopes but was less successful on higher $(530 \mathrm{~m})$, steeper $\left(c .30^{\circ}\right)$, more unstable slopes.

It has recently been conclusively shown (Harrod et al., 2000; McHugh et al., 2002) that sheep are a major driver of upland erosion in Britain, and that the area of grazing-induced erosion is increasing rapidly. Measures should therefore be taken to curtail such erosion. The findings outlined here could help in devising measures to combat erosion.

In this paper the small catchment of Hey Clough and its environs is described. How the eroding slopes were monitored is then outlined. The sequence of colonisation by vegetation of the bare eroding soils over a period of 32 years (1969-2001) is given, and the factors which control the rate of invasion discussed. The paper updates and expands on previous work (Evans, 1977, 1990, 1997). The long length of time over which monitoring has taken place allows a better understanding of the processes which have been at work and some of this knowledge has only become apparent in recent years. 


\section{Hey Clough and its environs}

Hey Clough, in the Peak District of central England (Figure 1), is 62.2ha and lies between 253 and $422 \mathrm{~m}$ above sea level, mostly above $380 \mathrm{~m}$. The first order stream drains north to Abbey Brook, a major east bank tributary of the upper River Derwent. The deeply incised valley is flanked by steep $\left(>20^{\circ}\right)$ slopes, steeper on the west, with gentler $\left(<10^{\circ}\right)$ slopes above. The northwest facing slopes of Back Tor, lie 1 km east of Hey Clough, at an altitude of 510-525m (Figure 1).

The climate is cool and wet, temperature ranges from a mean of $c .2^{\circ} \mathrm{C}$ in January to $c \cdot 14^{\circ} \mathrm{C}$ in July, and rainfall is $c .1300 \mathrm{~mm}$ per year. The underlying rocks are gritstones and shales of the Carboniferous Millstone Grit Series. Steeper and lower slopes carry soils of the Belmont association (SSEW, 1983; Ragg et al., 1984), mostly ironpan stagnopodzols, comprising in general coarse loamy very acid soils over rock with a wet peaty surface and a thin ironpan. Soils can be more clayey where over shale, and without an ironpan especially on steep slopes where soils are shallower. On gentle upper slopes very acid wet blanket peat of the Winter Hill association occurs.

The steeper slopes are covered by low acid grasses which are more palatable to sheep, especially wavy hair-grass (Deschampsia flexuosa), with less palatable matt-grass (Nardus stricta), bilberry (Vaccinium myrtillus), bracken (Pteridium aquilinum), and heather (Calluna vulgaris), although the last is also found on less steep poorly drained slopes. Gentler slopes are covered by tussocks of purple moor-grass (Molinia caerulea) and cotton-grass (Eriophorum sp).

Bare soil was exposed in a number of ways and was found in particular localities in Hey Clough in the mid-1960s. About 2.2\% of the catchment was bare of vegetation, and some of the bare soil 
was visibly eroding. Wavy hair-grass turf is prone to overgrazing and disruption of the surface by sheep and eroding scars (Evans, 1977) were mostly found there. Bare soil mostly occurred as discrete patches (scars), often bounded on the upslope side by a steep backwall and with the longest axis aligned along the contour. Smaller (type A) scars initiated by sheep (see Figure 1 in Evans, 1997) were often found at sharp convex changes of gradient on steep slopes and had a backwall: downslope length ratio of about 1:1. Larger (type B) scars initiated by sheep, often found on convex slopes of $10-15^{\circ}$, were elongated down slope and the ratio of the height of the backwall to downslope length was $>1: 5$ ). Patches of bare soil were often small in extent except along linear paths and tracks and adjacent to the stream (Table 1). Scars accounted for about onethird of the bare ground (Table 1) but patches of bare peat were extensively found where heather or Molinia plants had died due to overgrazing and trampling. Other patches of bare soil were formed where sheep 's hooves had broken through vegetation on very steep slopes, in cattle hoof prints, in water-cut channel sides or where the ground was very wet. Almost one-fifth of the bare soil could be attributed to sheep paths and to a vehicle track opened up in the north west of the catchment to give access to the higher parts of the basin. The sides of the track were often rubbed by sheep and its surface was constantly disturbed by them.

On the slopes of Back Tor the extensive zone of interconnecting scars (see Figure 2 in Evans, 1997) lay below a convex break of slope within a band of low well-grazed acid grasses separating tussocky Molinia dominated grassland. The gradient of the eroded slope is $c .12^{\circ}$. On photographs taken in 1975 neither heather nor bilberry is apparent.

\section{Monitoring}

As it was the larger scars which appeared to be eroding most rapidly in the mid-1960s it was decided that the bare soil patches monitored should be biased to the larger scars (Table 2). Table 
2 also gives a summary of some site characteristics of the scars. The scars were located throughout the catchment and lay on a route which could be easily identified and followed (Figure 1 inset).

Thirty two scars were monitored in the years 1966-68 to assess their rates of surface lowering and expansion or contraction in area. Surface lowering was assessed by measuring the height of exposed welding rod driven into the soil to rock (Evans, 1967a \& b) and the change in extent by measuring the distance between the edge of the scar and markers placed around the margins of the scar.

Between the 6th of March 1966 and 26th September 1968 Hey Clough was visited 221 times and field measurements were taken weekly between October 1966 and September 1968. The number of sheep present on the catchment was counted 114 times and when cattle were present (23 days) they too were counted. Surface lowering of one scar (number 32) was measured at weekly intervals, other scars at four-weekly intervals. Changes in scar area were assessed at 13 week intervals for 31 sites.

Hey Clough was revisited in May 1974 (Table 3) and a route was taken linking the 32 sites. Because many of the scars had changed greatly (see below) the catchment was visited the following year and monitoring began of the eroding slopes of Back Tor (Evans, 1990).

On 8 visits thereafter ( 1974-2001; see Table 3) a route linking the 32 scars in Hey Clough was taken and then Back Tor was visited. Scars were relocated where possible and photographed, except in 1980 when the weather was inclement. The bare soil exposed on Back Tor was photographed from the cairn on Lost Lad (Figure 1) c.250m away horizontally to the west-northwest. Photographs from Back Tor were taken using both 50mm and 200mm fixed focal length camera lens. 
The change in area of the bare soil exposed on Back Tor was assessed by counting the number of intersections on a 1mm square grid marked out on a transparent overlay which fell on what was interpreted to be bare soil. For photographs taken on the early visits the transparent grid was overlain over a mosaic of two enlargements of the photographs taken using the $50 \mathrm{~mm}$ lens. For later visits, to measure changes in area of bare soil more accurately, a mosaic of $200 \mathrm{~mm}$ lens photos was used. On most visits, but not all, the number of sheep present in Hey Clough was counted.

\section{Results}

\section{Hey Clough}

In the late 1960s, of the 31 sites in Hey Clough examined at 13 week intervals 22 were expanding in area, 8 were decreasing in size and one was stable. In 197410 of the 32 scars had been colonised by vegetation and in later years scars continued to be covered by vegetation, albeit at a slower rate, until by 2001 only 8 scars could be identified (Figure 2).

\section{Back Tor}

On Back Tor, in 1974 and 1975 the slopes were visibly eroding and peat was exposed at the surface. By 1986 all the peat had been stripped off (see Figure 7, Evans, 1990) and although the area of bare soil was still expanding, the rate of expansion was slower. By 1990 all the pale coloured Ea or Eag soil horizon below the peat had been stripped off exposing the brown B horizon below. Photographs show that in 1990 the backwalls of the scars were less disturbed by sheep and the backwall of the largest scar was in places completely covered and protected from 
the weather by heather and bilberry (Evans, 1992). In 1994 the backwalls had stabilised and were no longer being rubbed by sheep and the bare soil was largely colonised by grasses, especially wavy hair-grass which was setting seed. In 1998 and 2001 the scar was further covered by vegetation, heather becoming prominent. Compared to 1990, when the maximum extent of bare ground was recorded, by 2001 only about $20 \%$ of the surface was still free of vegetation and this was where the soil was more stony or where peat was still at the surface. Fencing was put up in 1993 around the eroding slopes to protect them from sheep. At the same time measures were taken to repair the footpath which traversed the slope. The footpath, although visible as a track across the vegetation in 1975, did not become obviously affected by erosion until the mid-1980s.

In 1980 the depth of soil exposed in the cliffed edges of the scars was recorded. The depth of horizons varied, the turf mat was $100-150 \mathrm{~mm}$ thick and overlay $150-400 \mathrm{~mm}$ of peat, which in turn was over a leached Ea or Eag horizon c.50mm thick on a mottled brown B horizon. It was estimated that $c .400 \mathrm{~mm}$ of soil had been stripped off, probably over a period of about 30 years, ie c.13mm per year. By 1986 most of the peat had gone and the pale coloured Ea or Eag horizon was exposed. In 1990 the pale coloured horizon too had gone. The estimated rate of erosion of the pale coloured horizon was c. $12.5 \mathrm{~mm}$ per year.

\section{Discussion}

\section{Hey Clough}

The rate at which scars were colonised by vegetation is a function of size, topsoil texture, surrounding vegetation and scar form. Of the 8 scars being colonised by vegetation in 1968 all, except one, were smaller in area than $0.55 \mathrm{~m}^{2}, 5$ were on peat surrounded by heather and 2 were on wet sites prone to seepage. Only two scars had a definite type A sheep scar form. Although 
one of these was, according to the measurements, declining in area in 1968, unlike the other scars soil was actively being deposited on the vegetation down slope of the scar.

Colonisation of scars was rapid in the first decade after 1968 but declined rapidly in rate thereafter (Figure 2). Of the ten scars that had become overgrown between 1968 and 1974 five were being colonised by vegetation in 1968 and one was stable. All the scars were small (had been $<1.25 \mathrm{~m}^{2}$ ) and were on peat. Nine were surrounded wholly or partly by low shrubs, either heather or bilberry, 6 were type A sheep scars with a low backwall $(<0.25 \mathrm{~m})$, and the remainder had no backwall.

By the following year (1975) a further 7 scars could not be relocated, 2 of these were being colonised by vegetation in 1968. The scars were small (had been $<0.63 \mathrm{~m}^{2}$ ), 5 were on peat and 2 on wet mineral soil sites. Except for one site, a small gravity slip, all scars had backwall heights less than $0.23 \mathrm{~m}$ high. In contrast to 1974 the scars were not surrounded by heather, 5 were surrounded by short acid grassland species and 2 with species (Juncus, mosses and thallophytes) indicating wetness. One scar could not be relocated in 1978. This was small, on peat and surrounded by heather.

A further 3 scars had disappeared by 1980, all were small (had been $<1.61 \mathrm{~m}^{2}$ ), 2 on mineral soil, one on peat, all were wholly or partly surrounded by short grass species and all had backwalls less than $0.38 \mathrm{~m}$ high. All the scars were overgrown by heather. One larger scar on peat, with a higher backwall had taken longer to disappear than other scars on peat. In 1980 the 11 surviving scars were those which in 1968 had been large in area, generally $>3.0 \mathrm{~m}^{2}$, though one scar was only $1.74 \mathrm{~m}^{2}$. However, even this was larger than the scars earlier colonised by vegetation. Although the area of scar 32 was not measured it was a large scar and was many square metres in area. 
In the following decade all 11 scars were relocated at every visit, but some scars were continuing to become overgrown. By 1994 two large type B scars on the western slopes (12 and 13, Figure 1 inset) had become overgrown by heather, as had by 2001 a large gravity scar (15) just above the valley floor on the west bank.

In 20018 scars were relocated, of which 5 could be definitely identified. All, except one, had been large scars $\left(>3.0 \mathrm{~m}^{2}\right)$. Most are now much smaller in area than they were and are often only recognisable because of their easily identifiable position within the landscape, for example where a path crosses the stream. All are in mineral soils and were within short grassland communities and all had high scar backwalls, more than $0.23 \mathrm{~m}$ tall, 7 more than $0.38 \mathrm{~m}$. Three type B sheep scars are now type A scars as the floor and downslope 'apron' of the scar have become covered by vegetation; grasses firstly, often wavy hair-grass with the unpalatable matt-grass, and later heather. The exceptions to this are scars 16, 17 and 19 on the eastern valley side (Figure 1 inset) which are still well-used by sheep for shelter, shade and scratching. They are all type A scars and had, and still have, high backwalls $(>0.61 \mathrm{~m})$. The floors of the scars are narrow, and in scars 16 and 17 are overhung by the arching backwalls. As the backwalls have retreated, the downslope margins have been colonised by grasses. The location of the scars may also be relevant to their longevity and the fact that they are still used by sheep. They all face west and are not far from each other, and are at or near the junction of vegetation types related to changes in slopes and soils. Above the scars are gentler slopes with Molinia, below steeper valley sides with short grasses and low shrubs. Scars 16 and 17 are on steep slopes (33 ${ }^{\circ}$ and $28^{\circ}$ respectively) whereas 19 is where the slope steepens from $15^{\circ}$ to $28^{\circ}$.

\section{Back Tor}

After 1982 the rate at which the bare ground was increasing in area declined becoming negative after 1990 and the extent of bare soil declined markedly. These changes, plus the stabilisation of 
the backwalls and the increase and changes in vegetation after 1986, imply that the colonisation of the bare soil had been going on for some time, not just since the eroding slopes were fenced off in 1993. In other words, the changes were primarily due to a reduction in sheep grazing intensity.

Where the repaired footpath climbs the slope of Back Tor it is noticeable that sheep still use these upper slopes. Sheep dung is present on the bare mineral soil adjacent to the path, which is disturbed and marked by hoof prints and scar backwalls are still rubbed. The fence enclosing the formerly eroding slope lies very close to the path and it is noteworthy that the mineral soil on the enclosed side of the fence has largely been colonised by vegetation and is no longer being disturbed by sheep. However, where the exposed peat backwall crosses the fence there is little difference in the vegetation cover on either side of the fence. This is also seen elsewhere along the fence.

Comparing results from both localities

Adjacent vegetation and scar colonisation. When comparing the findings from both localities there appears to be a paradox. In Hey Clough scars in peat were often those most rapidly colonised by vegetation, but this was not so on the slopes of Back Tor. However, in Hey Clough the scars were often small, surrounded by heather and were easily covered by invading heather plants. On the slopes of Back Tor, heather was not as extensive and the scars were large and interlinked.

Soils and colonisation. The scars on Back Tor are at a higher altitude and more exposed. Surface lowering was rapid until 1990 but probably almost ceased thereafter. Dry peat has a low bulk density and is easily broken down if the surface is exposed to sheep or weather, the light particles are easily blown or washed away. This rapidly shifting substrate is a hostile environment for 
seeds to germinate and grow, it is also acid, prone to temperature extremes and dries out rapidly.

It was noted on Back Tor, and has been seen elsewhere in the British uplands, that the thin $(c .50 \mathrm{~mm})$ leached pale coloured Ea or gleyed Eag horizon below the peat is also a hostile environment for plants to colonise. This is presumably because of its greater acidity and lower nutrient content than the brown B horizons below. The brown subsoil is often more compact and stonier and resistant to rain splash and wind. Hence it is a more stable environment in which seeds can germinate, especially if sheep are not present in sufficient numbers to greatly disturb the surface. Stones on the surface also provide shade and shelter under which the soil moisture content is higher and the conditions more favourable for seed germination.

Grazing intensity and colonisation. The harsh winter of 1968/69 led to a reduction in the numbers of sheep in the three moorland parishes covering the east side of the upper Derwent valley, from $25 \%$ at the minimum to $33 \%$ at the maximum. In Hey Clough this triggered the colonisation of the eroding scars by vegetation. After 1969 there was an increase in the numbers of sheep in the three parishes covering the Derwent moors (Evans, 1977) but in two of them (Bradfield and Derwent), the ones most relevant to this study, by 1975 the numbers had not risen to their pre-1969 level.

A reduction was made in the number of sheep grazing the Derwent moors in the mid-1980s when two holdings were merged into one (D Wilson, personal communication). Unfortunately, the agricultural census data which is collected in June every year is reported for each parish and not for individual farms, so parish data can only give an indication of what may have happened on an individual holding. The number of sheep on Hey Clough was not counted every visit, but between 1978 and 2001 counts were made on six visits. The numbers ranged from 8 to 107, with a mean of 82.8. These figures can be compared with those recorded on 114 visits between 9 March 1966 and 26 September 1968. The range was 31-274 and the mean 125.3. It appears 
grazing pressure in later years was reduced by $34 \%$.

To make a more valid comparison, to take into account the variability in numbers from week to week due to weather and management factors, the numbers of sheep on Hey Clough recorded between 1978 and 2001 were compared to those counted in 1966-68 for the nearest equivalent dates. In this instance the range was 43-228, with a mean of 117.1, a difference between the two periods of $29 \%$. The evidence from field counts suggests that grazing pressures on Hey Clough have been reduced since 1978 by about 30\%, and it is likely such differences apply to the upper slopes of Derwent Edge on which Back Tor is situated. There is evidence for there being fewer sheep on Back Tor in recent times. No sheep were seen on the slopes of Back Tor in 1975 and 1978. However, in 1982 and 19864 sheep were seen but since then none.

In the late 1960s, on average 125 sheep (ewes+lambs) per week grazed Hey Clough, an intensity of 1 sheep per 0.5 ha. This is a mean for the whole catchment and grazing pressures varied across the catchment according to vegetation type (Evans, 1977). The expansion of bare soil stopped in Hey Clough when grazing pressures were reduced by c.30\%. On average about 83 sheep now graze Hey Clough, a year-round grazing intensity of 1 sheep per $0.75 \mathrm{ha}$.

It is postulated that summer grazing intensities that initiate bare soil in short grass swards lie between 0.2-0.4 ha per sheep (Evans, 1997 \& 2000) and for peat moors 1 sheep per 2.0ha. This work implies that lowering summer-grazing intensities by c.30\%, to 1 sheep to $0.26-0.52$ ha for short grass swards on mineral soils and 1 sheep per 2.6ha for tussocky grass swards on peat, will curtail erosion. Anderson and Radford (1994) found that reducing summer-grazing intensities on the western slopes of Kinder Scout in the Peak District between 1982 and 1990, from 1 sheep per 0.4ha to 1 per 2.3-5.6ha greatly stimulated vegetation colonisation of the eroding bare soils. However, factors other than a reduction in grazing pressure may also have a bearing on the colonisation of bare soil by vegetation (see below). 
Decline in extent of bare soil. Within 6 years 17 of 32 (53\%) monitored scars in Hey Clough could not be relocated and by 1980 the number had risen to 20 (62\%). Large parts of the bigger but still visible scars had also become overgrown. It is not possible to estimate accurately the area of bare soil grown over in this 11 year period but a crude assessment can be made. The average size of scar was small (Table 1) and most of the sheep scars except for the larger ones, most if not all the bare patches in heather, as well as the hoof prints and dead tussocks must have become overgrown. Field observation suggested that the areas of bare soil within patches of burnt heather moor had also been colonised. From ground photographs it is conservatively estimated that at least half the bare soil of the larger scars and of the large patches of bare soil exposed along the track in the north-west of the catchment had become covered by vegetation. By 1980 probably at least 70\% of the former area of bare soil in Hey Clough had been colonised by vegetation.

Between 1990 and 2001 about 80\% of the eroding bare soil on Back Tor had become colonised by vegetation, a figure not dissimilar to that for Hey Clough for a similar period of time. Anderson and Radford (1994) note that on the formerly eroding western slopes of Kinder Scout, 12km west-south-west of Hey Clough, in 8 years 90\% vegetation cover was reached on the less steep lower slopes and on the very steep more unstable slopes at higher altitude $76 \%$ cover.

The rate of colonisation of bare soil is rapid therefore, once the process begins. On Back Tor, however, colonisation did not begin after grazing pressure declined due to natural circumstances in 1969 nor in the late 1980s when a permanent reduction of grazing pressure came about because of land management agreements. In total it took 21 years for the stabilisation of the margins of the sheep scars on Back Tor and for the soil surface to become an environment favourable to successful seedling germination. 
It is probably no coincidence that vegetation did not start to colonise the surface until after 1990 when the peat and pale coloured horizons had been stripped off (see above). In this instance, therefore, a reduction in grazing pressure only was not sufficient to curtail erosion as the soils were too vulnerable to erosion. Anderson and Radford (1994) note that on steep unstable slopes there was a delay in the onset of colonisation of bare soil and that it proceeded at a slower pace.

Other factors that encouraged erosion in the 1960s. The rapid rate of recovery of eroding slopes on Kinder Scout is not unexpected in view of the great reduction in stocking rate, a factor of between 5-14, and with regard to what happened in Hey Clough. However, although the recovery was rapid too in Hey Clough the reduction in stocking rate was much less, only about $30 \%$. It may be that the conditions pertaining in the 1960 s were particularly conducive to the initiation of erosion. Thus, cattle (cows and calves) grazed the slopes to the east of the River Derwent. They ranged widely and were not always present in the catchment, being noted on only 23 occasions and not at all during the winter of 1967/68. The numbers recorded range from 5 to 41, with an average of 17.2 cattle per siting. Their impacts on the slopes were marked, not only their hoof prints, especially on bare soil, but they also disturbed instruments for measuring slope processes and rainfall. No cattle were seen on the catchment after 1968.

From the mid-1940s to the late 1960s the air temperature at Buxton declined (see Figure 5 in Evans, 1977), although not in a continuous manner. The growing season shortened by 30 days or so. Although temperatures at Buxton between 1944-73 do not mirror exactly the 'central England' temperatures (Hulme, 1999), they relate well to them. After the mid-1960s in the lowlands and the late 1960s in the uplands temperatures began to rise. Holden and Adamson (2002) have suggested the warming since the mid-1980s is more marked in the north Pennines than it is in the adjacent Durham lowlands and that it is the winters, rather than the summers, which are becoming warmer. During the earlier period the shortening growing season in the Peak District would have exacerbated the increasing grazing pressures which came about after the 
1947 Agriculture Act which brought in sheep headage payments and would have lowered the erosional threshold. Whereas the longer and warmer growing seasons thereafter would have encouraged vegetation growth and raised the erosional threshold and could also partly explain the rapid colonisation of bare soil in the early 1970s and afterward.

Other impacts of reduced grazing pressure Heather especially, as well as bilberry, have come back vigorously on the formerly eroded slopes where they had been present previously and where there was still a seed bank in the soil. Burning is still practised within the heather moor in Hey Clough, but no longer seems to create the conditions for the initiation of erosion. Probably because the grazing threshold is no longer surpassed. However, the lowering of grazing pressures has not yet induced heather to colonise those areas of Molinia grassland where presumably there is no longer a heather seed bank or the vegetation mat is now too thick to provide a favourable environment for heather seedling germination and growth. Since 1990 it has been noted that where heather has grown on steep slopes and gained a sufficient height $(>1 \mathrm{~m})$ and density to inhibit movement of the sheep through it, tree saplings are now growing vigorously (up to $0.3 \mathrm{~m}$ per year). At lower altitudes the seed source is the occasional birch (Betula sp.), at higher altitudes it is rowen (Sorbus acuparia). The trend in Hey Clough is to a more diverse ecology therefore and probably to greater slope stability.

\section{Conclusions}

In the 1960s slopes in Hey Clough and on Back Tor were eroding rapidly. This erosion was brought about mainly by an increase in grazing pressure as sheep numbers rose after 1947, but a cooling climate and the presence of cattle on the slopes exacerbated the situation.

A decline in the number of sheep grazing Hey Clough, by c.30\%, climate warming and the 
removal of cattle all encouraged rapid colonisation of the eroding bare soil by grasses and later, if a seed bank was present, by heather and bilberry. Much of the colonisation took place over the first 5-10 years after grazing pressures were reduced.

The sequence of disappearance of scars on Hey Clough is: smaller scars before larger; scars on peat before scars on mineral soils; scars on wet mineral soils before scars on drier sites; scars within heather moor before scars within low grassland; scars without (micro-) cliffed margins before sheep scars; and the larger type B scars before the larger type A scars. The scars remaining are still used by sheep and have been or have become type A sheep scars.

Scars on Back Tor, unlike those in Hey Clough, were not colonised rapidly because the unstable peat surface and the leached pale coloured (Ea or Eag) horizon below are hostile environments for seedling germination and it was not until these were stripped off that colonisation began. It was then rapid. There is an important implication arising from this finding. Thus, erosion of peat, once started, is likely to continue until the peat and the underlying leached infertile Ea or Eag horizon below are stripped off. It is likely such findings also apply where an unstable subsoil is close to the surface, such as shallow $(<300 \mathrm{~mm})$ ranker or rendzina soils over scree. In localities with peat or ranker soils or other shallow soils over scree therefore grazing pressures should not be allowed to cross the erosion threshold, likely to be a summer grazing intensity of $c .1$ sheep per 0.2ha.

To avoid crossing this threshold, vulnerable slopes need to be monitored to assess grazing pressure and to look for signs of the onset of erosion. Such monitoring could be done as part of the 'broad and shallow' whole-farm auditing schemes proposed by the Policy Commission on the Future of Farming and Food (the Curry Report, PCFFF, 2002) and by the Environment Agency (EA, 2002). Such schemes are proposed to bring about a more sustainable way of farming. They have come about partly because of the disease implications of modern farming, such as the 
recent foot and mouth epidemic in Britain and the recognition that modern farming is not always kind to the environment, and partly because of a European Union drive to cut down the overproduction of crops and livestock which can lead to dumping on the world market with severe impacts on prices and agricultural economies in countries in the developing and less developed world. Such schemes could be funded through the English Rural Development Regulation as proposed in the mid-term review of the European Union's Common Agricultural Policy (CEC, 2002).

\section{Acknowledgements}

John Walsh drew the diagrams. I am grateful to the referees for their helpful comments.

\section{References}

Anderson, P. \& Radford, E. (1994). Changes in vegetation following reduction in grazing pressure on the National Trust's Kinder Estate, Peak District, Derbyshire, England. Biological Conservation 69, 55-63.

Anderson, P. \& Yalden, D. W. (1981). Increased sheep numbers and the loss of heather moorland in the Peak District, England. Biological Conservation 20, 195-213.

CEC (2002). Mid-Term Review of the Common Agricultural Policy. Communication from the Commission to the Council and the European Parliament. COM (2002) 394 final, Commission of the European Communities, Brussels.

EA (2000). The State of the Environment in England and Wales: The Land. Commissioned by Environment Agency. The Stationery Office, London.

EA (2002). Agriculture and natural resources: benefits, costs and potential solutions. 
Environment Agency, Bristol.

Evans, R. (1967a). On the use of welding rods for erosion and deposition pins. Revue de Geommorphogie Dynamique 17, 165.

Evans, R. (1967b). Modified depth gauge for erosion rod measurements. Revue de Geomorphologie Dynamique 17, 165.

Evans, R. (1971). The need for soil conservation. Area 3, 20-23.

Evans, R. (1974). A study of selected slope erosion processes acting on slopes in a small drainage basin. Unpublished PhD Thesis, University of Sheffield

Evans, R. (1977). Overgrazing and soil erosion on hill pastures with particular reference to the Peak District. Journal of the British Grassland Society 32, 65-76.

Evans, R. (1990). Erosion studies in the Dark Peak. Proceedings of the North of England Soils Discussion Group 24, 39-61.

Evans, R. (1992). Erosion of rough grazings in Britain. In J Boardman, Post-Congress Tour Guide. First International ESSC Congress, pp. 18-22, European Society for Soil Conservation: Bedford.

Evans, R. (1997). Soil erosion in the UK initiated by grazing animals: a need for a national survey. Applied Geography 17, 127-141.

Evans, R. (1998). The erosional impacts of grazing animals. Progress in Physical Geography 22, 251-268.

Evans, R. (2000). Appendix D) Scar initiation. In Harrod T R and 11 others, Research on the quantification and causes of upland erosion. Study Number JX4118E, Report to the Ministry of Agriculture, Fisheries and Food, Soil Survey and Land Research Centre: Cranfield University.

Harrod T. R., McHugh, M., Appleby, P. G., Evans, R., George, D. G., Haworth, E. Y., Hewitt, D., Hornung, M., Housen, G., Leekes, G., Morgan, R. P. C. and Tipping, E. (2000). Research on the quantification and causes of upland erosion. Study Number JX4118E, Report to the Ministry of Agriculture, Fisheries and Food, Soil Survey and Land Research Centre: Cranfield 
University.

Holden, J. and Adamson, J. K. (2002). The Moor House long-term upland temperature record: new evidence of recent warming. Weather 57 119-127.

Hulme, M. (1999). Air temperature in central England. In M. G. R. Cannell, J. P. Palutikof and T. H. Sparks, Indicators of climate change in the UK, pp. 6-7, DETR: Wetherby.

McHugh, M., Harrod, T. and Morgan, R. (2002). The extent of soil erosion in upland England and Wales. Earth Surface Processes and Landforms 27, 109-114.

Oldeman, L.R., Hakkeling, R.T.A. and Sombroek, W.G. (1991). World Map of the Status of Human-Induced Soil degradation. An explanatory note. Global Assessment of Soil Degradation GLASOD, second revised edition. International Soil Reference and Information Centre, Wageningen: United Nations Environment Programme, Nairobi.

PCFFF (2002). Farming \& Food. A sustainable future. Report of the Policy Commission on the Future of Farming and Food, Cabinet Office, London.

Phillips, J., Yalden, D. and Tallis J. (eds) (1981). Peak District Moorland Erosion Study. Phase 1 Report. Peak Park Joint Planning Board: Bakewell.

Ragg, J. M., Beard, G. R., George, H., Heaven, F. W., Hollis, J. M., Jones, R. J. A., Palmer, R. C., Reeve, M. J., Robson, J. D. and Whitfield, W. A. D. (1984). Soils and their Use in Midland and Western England. Soil Survey of England and Wales: Harpenden.

SSEW (1983). Soils of Midland and Western England. Soil Survey of England and Wales: Harpenden.

Wilson, D. (1993). Ten years on: Kinder Scout. ENACT 1, 4-6.

Yalden, D. W. 1972 The red grouse (Lagopus Lagopus Scoticus (LATH.) in the Peak District. Naturalist 92 (check), 89-102 
Table 1. Extent and size of patches (scars) of bare soil in Hey Clough in 1966, based on randomly selected $30.5 \mathrm{~m}$ squares covering $10 \%$ of the catchment.

\begin{tabular}{|c|c|c|c|c|c|}
\hline Type of bare ground & $\begin{array}{l}\text { Area } \\
\left(\mathrm{m}^{2}\right)\end{array}$ & $\begin{array}{l}\text { \% total } \\
\text { area bare }\end{array}$ & $\begin{array}{l}\text { Number } \\
\text { of scars }\end{array}$ & $\begin{array}{l}\text { \% total } \\
\text { number }\end{array}$ & $\begin{array}{l}\text { Mean area } \\
\text { scar }\left(\mathrm{m}^{2}\right)\end{array}$ \\
\hline & & soil & & scars & \\
\hline Scars caused by sheep & 474.9 & 34.6 & 1281 & 37.0 & 0.37 \\
\hline Bare patches in 341.5 & 24.9 & 986 & 28.5 & 0.34 & \\
\hline Heather & & & & & \\
\hline Path and track & 225.8 & 18.4 & 118 & 3.4 & 2.13 \\
\hline Burnt moor & 149.3 & 10.9 & - & - & - \\
\hline Gravity/steep slopes & 109.2 & 8.0 & - & - & - \\
\hline Saturated ground & 16.5 & 1.2 & 33 & 0.9 & 0.50 \\
\hline By gullies and & 14.7 & 0.9 & 3 & 0.1 & 4.27 \\
\hline Waterfalls & & & & & \\
\hline Hoof prints & 11.5 & 0.8 & 986 & 28.5 & 0.01 \\
\hline Dead tussocks & 2.6 & 0.2 & 57 & 1.6 & 0.04 \\
\hline
\end{tabular}


Table 2. Summary of some characteristics of the scars monitored in Hey Clough 1966-68

$\begin{array}{lccccc}\text { Area }-\mathrm{m}^{2} & \text { Number } & \text { Type } & \text { Number } & \text { Vegetation type } & \text { Number } \\ <1 & 19 & \text { type A } & 19 & \text { Short grasses } & 21 \\ 1-10 & 8 & \text { type B } & 5 & \text { Short grasses/ } & 4 \\ 11-20 & 2 & \text { patch in } & 4 & \text { heather } & \\ >20 & 2 & \text { heather } & \text { Short grasses/ } & 4 \\ \text { Mean of } 31 \text { sites }-3.29 \mathrm{~m}^{2} & \text { gravity } & 3 & \text { bilberry } & \\ \text { Range of } 31 \text { sites }-0.10-22.97 \text { hoofprint } 1 & \text { Heather } & \\ & & \text { Molinia/ } & & \end{array}$

$\begin{array}{lclc}\text { Soil type } & \text { Number } & \text { Slope gradient }\left(^{\circ}\right) & \text { Number } \\ \text { peat } & 16 & 0-10 & 3 \\ \text { mineral } & 13 & 11-20 & 14 \\ \text { peat/mineral } & 3 & \text { straddles 0-20 } & 2 \\ \text { 21-30 } & & 4 & \\ \text { straddles 11-30 } & 3 & \\ 31-40 & & 2 \\ 41-50 & & \end{array}$


Table 3. Date of field visits to Hey Clough and Black Tor

$\begin{array}{rll}4 & \text { May } & 1974 \\ 28 & \text { October } & 1975 \\ 28 & \text { June } & 1978 \\ 5 & \text { September } & 1980 \\ 28 & \text { June } & 1982 \\ 10 & \text { July } & 1986 \\ 5 & \text { September } & 1990 \\ 2 & \text { September } & 1994 \\ 30 & \text { October } & 1998 \\ 1 & \text { August } & 2001\end{array}$

\section{Figures}


1 Hey Clough and its environs

2 Number of erosion scars found in Hey Clough on each visit

3 Area and rate of expansion of bare soil on Back Tor, 1948-2001 